\title{
Interleukin 1: a Mitogen for Human Vascular Smooth Muscle Cells That Induces the Release of Growth-Inhibitory Prostanoids
}

\author{
Peter Libby, Stephen J. C. Warner, and Gary B. Friedman \\ Department of Medicine and United States Department of Agriculture Human Nutrition Research Center, \\ Tufts University, Boston, Massachusetts 02111
}

\begin{abstract}
There is much interest in defining the signals that initiate abnormal proliferation of cells in a variety of states characterized by the presence of mononuclear phagocytes. Since $\mathrm{IL}-1$ is a major secretory product of activated human monocytes we examined whether this cytokine can stimulate the growth of human vascular smooth muscle cells (SMC). Neither recombinant IL-1 (rIL-1) $\alpha(\leq 5.0 \mathrm{ng} / \mathrm{ml})$ nor $\beta(\leq 100 \mathrm{ng} / \mathrm{ml})$ stimulated SMC growth during $2-d$ incubations under usual conditions. IL-1 did stimulate SMC to produce prostanoids such as $\mathrm{PGE}_{1}$ or $\mathrm{PGE}_{2}$ that can inhibit SMC proliferation. When prostaglandin synthesis was inhibited by indomethacin or aspirin both rIL-1 $\alpha$ and $\beta$ ( $\geq 1 \mathrm{ng} / \mathrm{ml})$ markedly increased SMC growth. In longer-term experiments (7-28 d) rIL-1 stimulated the growth of SMC even in the absence of cyclooxygenase inhibitors. The addition of exogenous $\mathrm{PGE}_{1}$ or $\mathrm{PGE}_{2}$ (but not $\mathrm{PGF}_{1 \alpha}, \mathrm{PGF}_{2 \alpha}, \mathbf{P G I}_{2}$ ) to indomethacin-treated SMC blocked their mitogenic response to rIL-1. Antibody to IL-1 (but not to platelet-derived growth factor [PDGF]) abolished the mitogenic response of SMC to rIL-1. Exposure of SMC to rIL-1 or PDGF caused rapid (maximal at $1 \mathrm{~h}$ ) and transient (baseline by $3 \mathrm{~h}$ ) expression of the c-fos proto-oncogene, determined by Northern analysis. We conclude that IL-1 is a potent mitogen for human SMC. Endogenous prostanoid production simultaneously induced by IL-1 appears to antagonize this growthpromoting effect in the short term ( 2 d) but not during more prolonged exposures. IL-1 produced by activated monocytes at sites of tissue inflammation or injury may thus mediate both positive and negative effects on SMC proliferation that are temporally distinct.
\end{abstract}

\section{Introduction}

The control of cellular proliferation is a fundamental biological problem that has considerable practical importance in relation to certain human diseases. For example, the pathogenesis of atherosclerosis and hypertension involve abnormal proliferation of smooth muscle cells (SMC) ${ }^{1}$ within the arterial

A preliminary report of this work was presented as an abstract in 1987 (Clin. Res. 35:297 A).

Address correspondence to Dr. Libby, Tufts University, 711 Washington St., Boston, MA 02111.

Received for publication 30 June 1987 and in revised form 14 September 1987.

1. Abbreviations used in this paper: ASA, acetylsalicylic acid; FGF, fibroblast growth factor; HSVSMC, human saphenous vein SMC; IT,

J. Clin. Invest.

(C) The American Society for Clinical Investigation, Inc.

$0021-9738 / 88 / 02 / 0487 / 12 \$ \$ 2.00$

Volume 81, February 1988, 487-498 wall $(1,2)$. Definition of factors that may regulate proliferation of these cells has received considerable attention over the last dozen years. The platelet was an early contender as the source of mitogens that stimulate the growth of SMC during atherogenesis (3). However, in the cholesterol-fed animal, SMC proliferation commences while the endothelial monolayer that lines the vessel's lumen remains intact, and before the adherence and degranulation of platelets at the site of the lesion (4). These observations indicate that initiation of atherogenesis in vivo does not require products released from platelets.

Morphologic studies of the sequence of events in the wall of arteries of animals fed cholesterol have stimulated interest in the role of phagocytic leukocytes in plaque formation. Soon after initiation of cholesterol feeding, blood monocytes adhere to the arterial intima and diapedese through its yet intact endothelial monolayer (5-9). Focal accumulations of lipid-laden macrophages in the intima characterize the fatty streak, the lesion that precedes the complicated fibrous plaque characteristic of advanced atherosclerosis, and that contains accumulations of SMC in addition to phagocytes $(10,11)$. These observations have focused attention on monocyte products that may stimulate the proliferation of mesenchymal cells such as $\operatorname{SMC}(12,13)$.

One of the mitogens secreted by activated mononuclear phagocytes resembles platelet-derived growth factor (PDGF). Upon stimulation, human monocytes can transcribe the genes that encode both chains of PDGF and secrete material that cross reacts immunologically with PDGF purified from human platelets and that shares its mitogenic activity (14-16). Monocytes also produce the mitogen transforming growth factor $\alpha$ (Madtes, D. K., E. W. Raines, K. S. Sakariassen, R. K. Assoian, M. B. Sporn, G. I. Bell, and R. Ross, personal communication) as well as material that resembles fibroblast growth factor (FGF) (17). Upon activation, these cells secrete large amounts of the multipotent mediator IL-1 $(18,19)$. Among the many functions ascribed to the IL-1 family of molecules is the ability to stimulate the proliferation of human fibroblasts (20), although its mitogenic effects on these cells can be weak or inconsistent (21). IL-1 does have a degree of sequence homology with the acidic FGF family (22). Therefore, it was of interest to determine if IL-1 also promoted the growth of human vascular SMC and might thus participate in the abnormal proliferation of this cell type that occurs early in atherogenesis.

In previous studies we failed to demonstrate a mitogenic effect of IL-1 on vascular SMC from a variety of species generally studied over a 2-d period (23). IL-1 characteristically stimulates the production of prostaglandins from target tissues, and

serum-free chemically defined medium supplemented with insulin (1 $\mu \mathrm{M})$ and transferrin $(5 \mu \mathrm{g} / \mathrm{ml})$; PDGF, platelet-derived growth factor; PDS, plasma-derived serum; rIL-1, recombinant human IL-1; SMC, smooth muscle cells. 
SMC also respond to IL-1 by increased production of $\mathrm{PGE}_{2}$ (24-26). Since prostaglandins of the E series can inhibit mitogen-induced proliferation of cultured vascular SMC (27), in our previous experiments endogenous prostanoids induced by IL-1 might have masked a direct mitogenic effect of this hormone. Our earlier study of the proliferative action of IL-1 on mesenchymal cells used material purified from activated human monocytes that contained an incompletely defined mixture of the two known species of human IL-1, $\alpha$ and $\beta$. The present study used homogenous preparations of IL- $1 \alpha$ and $\beta$ produced by recombinant DNA technology from genes cloned from human monocytes $(28-30)$ to reexamine the possible mitogenic effect of IL-1 on vascular SMC during longer periods of exposure, and under conditions that prevented the synthesis of endogenously produced prostanoids.

\section{Methods}

Cell preparation, culture, and characterization. SMC were prepared from human saphenous veins by explant outgrowth techniques (31). The saphenous vein specimens were trimmings obtained at coronary artery bypass surgery. This use of usually discarded tissue was approved by the Human Investigation Review Committee of New England Medical Center. The cell cultures were maintained in DME buffered with Hepes (25 mM) (M. A. Bioproducts, Walkersville, MD). Very low concentrations of bacterial endotoxin $(<100 \mathrm{pg} / \mathrm{ml})$ can stimulate endogenous IL-1 production by these cells (32). Endotoxin contamination of tissue culture reagents could thus confound the results of study of the effects of exogenous recombinant IL-1 (rIL-1) preparations. Therefore, constituents of tissue culture media were screened for endotoxin contamination using the quantitative chromogenic limulus amoebocyte lysate assay (QCL 1000; M. A. Bioproducts). Only materials with endotoxin levels $<40 \mathrm{pgs}$ per $\mathrm{ml}$ were used in these experiments. In addition, the endotoxin antagonist polymyxin B $(10 \mu \mathrm{g} / \mathrm{ml})$ was included in all experimental incubations.

These cells cultured from saphenous vein explants (passage 2 to 5) exhibited typical morphologic characteristics of vascular smooth muscle in vitro including a pattern of growth in hills and valleys (31). Even after three passages in culture the majority of these cells exhibited specific immunofluorescence when stained with a monoclonal antibody that selectively recognizes muscle forms of actin (HHF 35). This reagent does not react with endothelial cells or fibroblasts (33). These immunofluorescence studies were kindly performed by Dr. T. Tsukada, E. W. Raines, Dr. A. M. Gown, and Dr. R. Ross of the Department of Pathology, University of Washington, Seattle, WA. Human aortic SMC were isolated enzymatically from the inner third of the tunica media of human arteries obtained from transplant donors with the cooperation of the New England Organ Bank (34).

Reagents. IL- $1 \alpha$ prepared by recombinant DNA technology in Escherichia coli was provided by Dr. Peter T. Lomedico of HoffmanLa Roche Inc., Nutley, NJ. This preparation consists of the carboxyterminal 154 amino acids of the 271 residue human IL-1 $\alpha$ precursor (30). IL-1 $\beta$ (residues 112 to 269 ) produced by recombinant DNA technology in $E$. coli was supplied by Dr. Charles A. Dinarello, Tufts University (35). Dr. Dinarello also supplied an ammonium sulfate (40\% saturated) precipitate from rabbit anti-serum raised against human rIL-1 $\alpha$. We prepared an IgG fraction from this material by protein A affinity chromatography.

Highly purified PDGF from human platelets was provided by Elaine W. Raines and Russell Ross (36). These investigators also generously supplied us with goat anti-human PDGF IgG. The probe used to detect c-fos mRNA was a 1-kb Eco RI fragment of v-fos proviral DNA (37). The cDNA probe used to detect $\beta$-tubulin transcript was a highly conserved $1 \mathrm{~kb}$ segment of a rat $\beta$-tubulin gene from pSP-6 RBT.3 (38) that encodes a protein constitutively expressed in many tissues. We prepared this construct from a cDNA clone provided by
Dr. Stephen R. Farmer of Boston University Medical School, Boston, MA (39). The cyclooxygenase inhibitors indomethacin and acetylsalicylic acid (ASA) (aspirin) were purchased from Sigma Chemical Co., St. Louis, MO.

Growth assays. For growth assays, cells were subcultured into 24well plates at $3 \times 10^{4} \mathrm{~cm}^{-2}$ or in 96 -well plates at $0.9-2 \times 10^{5} \mathrm{~cm}^{-2}$. The cultures in 24-well plates were maintained in DME with FCS (10\%) until they were postconfluent (11-14 d postsubculture). One day before initiation of growth studies, these cultures were placed in medium composed of equal parts of DME and Ham's F-12 medium (M. A. Bioproducts) lacking serum but supplemented with insulin $(1 \mu \mathrm{M})$ and transferrin $(5 \mu \mathrm{g} / \mathrm{ml})$ (Collaborative Research, Bedford, MA), a medium denoted IT. This incubation in serum-free medium was designed to deprive the cells of serum-associated mitogens and produce growth arrest in an attempt to synchronize cell proliferation in response to mitogens added during growth assays (40). The cultures in 96-well plates were used for experiments $2 \mathrm{~d}$ after subculture without preincubation in serum-free medium unless otherwise specified.

Incorporation of tritiated TdR $(6 \mathrm{Ci} / \mathrm{mmol}, \mathrm{ICN}$ Radiochemicals, Irvine, CA) was measured in short-term assay by addition of the labeled TdR $(0.05 \mu \mathrm{Ci} / \mathrm{ml}$ for 24 -well plates; $0.25 \mu \mathrm{Ci} / \mathrm{ml}$ for 96 -well plates) during the second $24 \mathrm{~h}$ of a $48-\mathrm{h}$ incubation. In pilot experiments on human saphenous vein SMC (HSVSMC), this schedule of labeling maximized stimulation of TdR incorporation exposed to a known mitogenic stimulus, FCS. At the end of the incubation unincorporated precursor was removed by treatment with perchloric acid $(0.2 \mathrm{M})$ or by washing with distilled water cell residues collected on filter paper by an automated cell harvester. Radioactivity was measured by liquid scintillation spectroscopy, and efficiency of counting was determined by use of an external standard.

DNA measurements were made on perchloric acid-treated cell layers by a fluorimetric procedure based on binding of bisbenzamide (Calbiochem-Behring Diagnostics, La Jolla, CA) $(40,41)$. As an additional index of culture mass, cells were stained with the protein-binding dye amido black 10B (napthol blue black or buffalo black NBR; Sigma Chemical Co.) according to the method of Vilček et al. (42). For this assay the layers were fixed in formalin $(10 \%)$ in sodium acetate buffer $(0.1 \mathrm{M})$ for $15 \mathrm{~min}$, and treated with a solution of the dye $(0.5 \%)$ in acetic acid $(9 \%)$ with sodium acetate $(0.1 \mathrm{M})$ for $10-30 \mathrm{~min}$. After three washes in distilled water to remove unbound dye, the cell layers could be photographed. Subsequently, the bound dye was extracted in sodium hydroxide $(50 \mathrm{mM})$ and the absorbance of this solution at 630 nm measured.

Measurement of prostaglandins. The major prostanoids produced by human vascular smooth muscle are $\mathrm{PGE}_{2}, \mathrm{PGF}_{2 \alpha}$, and prostacyclin $(25,43-45) . \mathrm{PGE}_{2}, \mathrm{PGF}_{2 \alpha}$, and the stable metabolite of prostacyclin, 6-keto $\mathrm{PGF}_{1 \alpha}$, were measured in the supernatants of SMC cultures using radioimmunoassay. The prostanoids were extracted from the acidified culture media with ethyl acetate. After drying by vacuum evaporation, the residue was dissolved in phosphate buffer that contained bovine $\gamma$-globulin. Assays for the prostanoids used commercial radioimmunoassay kits according to the manufacturer's recommendations (Seragen Inc., Boston, MA). The antibody used for the $\mathrm{PGE}_{2}$ assay crossreacts completely with $\mathrm{PGE}_{1}, 1.3 \%$ with $\mathrm{PGF}_{2 \alpha}$ and $<1 \%$ with 6-keto $\mathrm{PGF}_{1 \alpha}$. The antibody used to detect $\mathrm{PGF}_{2 \alpha}$ crossreacts completely with $\mathrm{PGF}_{1 \alpha}, 1.1 \%$ with $\mathrm{PGE}_{1}, 1.1 \%$ with 6-keto $\mathrm{PGF}_{1 \alpha}$, and $0.3 \%$ with $\mathrm{PGE}_{2}$. The antibody used to detect 6-keto $\mathrm{PGF}_{1 \alpha}$ crossreacts $7.8 \%$ with $\mathrm{PGF}_{1 \alpha}, 6.8 \%$ with 6 -keto $\mathrm{PGE}_{1}, 2.2 \%$ with $\mathrm{PGF}_{2 \alpha}, 0.7 \%$ with $\mathrm{PGE}_{1}$, and $0.6 \%$ with $\mathrm{PGE}_{2}$.

$R N A$ extraction and blot hybridizations. RNA was extracted from SMC by treatment with guanidinium isothiocyanate and isolated by centrifugation through cesium chloride (46). For Northern blotting, 10 $\mu \mathrm{g}$ of total cellular RNA was applied to each lane. DNA probes were labeled by nick translation with $\mathrm{dCT}^{32} \mathrm{P}$ and $\mathrm{dGT}^{32} \mathrm{P}$ (New England Nuclear, Boston, MA) to specific activities $>5 \times 10^{8} \mathrm{cpm} / \mu \mathrm{g}$ DNA. Electrophoresis and transfer to nylon membranes (Hybond-N; Amersham Corp., Arlington Heights, IL), fixation, hybridization, and autoradiography used standard techniques $(32,38)$. 


\section{Results}

IL-1 stimulates the growth of cultured human vascular SMC in the presence of a cyclooxygenase inhibitor. Incubation of SMC cultured from adult HSVSMC in DME with FCS (5\%) that contained various concentrations of rIL-1 $\alpha$ or $\beta$ did not increase TdR incorporation, which was measured during the final $24 \mathrm{~h}$ of the 48 -h experiment (Fig. 1, $A$ and $B$, open squares). These results agree with our previous studies that used IL-1 purified from activated human blood monocytes (23). IL-1 stimulates prostanoid production by SMC, and certain prostaglandins can inhibit the proliferative response of these cells to PDGF (27). Therefore, we performed this experiment in parallel on cells incubated with the cyclooxygenase inhibitor indomethacin at a concentration $(1 \mu \mathrm{g} / \mathrm{ml})$ that completely blocks the synthesis of $\mathrm{PGE}_{2}$ by these cells (Table I) (26). Under this condition, both species of rIL-1 increased TdR incorporation even at the lowest concentration tested (Fig. 1, $A$ and $B$, closed squares).

Thymidine incorporation alone is a potentially misleading index of cell proliferation and may not reflect the actual rate of

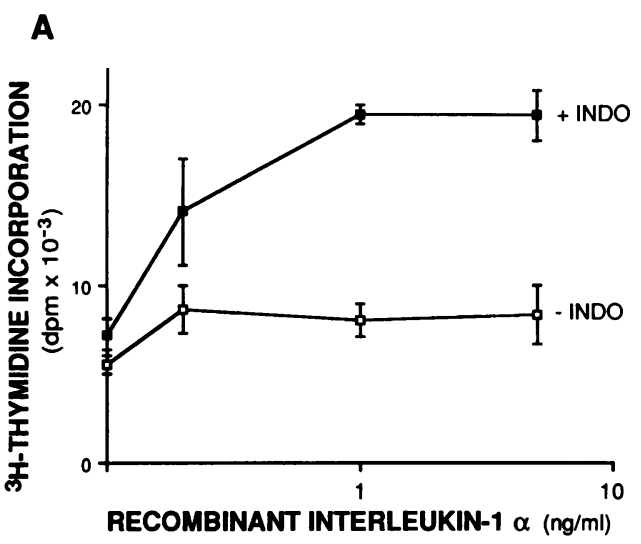

B

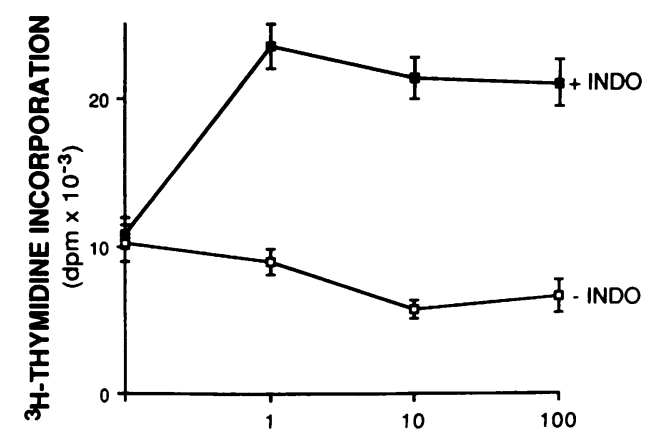

RECOMBINANT INTERLEUKIN-1 $\beta \quad(\mathrm{ng} / \mathrm{ml})$

Figure 1. Concentration dependence of rIL-1-induced stimulation of TdR incorporation by human vascular SMC with or without indomethacin. Cultures of HSVSMC in 24-multiwell plates were incubated for $48 \mathrm{~h}$ with the indicated concentrations of rIL-1 $\alpha(A)$ or $\beta$ $(B)$. In the absence of indomethacin there was little or no change in TdR uptake measured between 24 and $48 \mathrm{~h}$ during this $2-\mathrm{d}$ incubation (open squares). In the presence of indomethacin $(1 \mu \mathrm{g} / \mathrm{ml}) \mathrm{rIL}-1$ increased TdR uptake by HSVSMC (closed squares). The data points represent the mean of six observations and the error bars the SD.
Table I. rIL-1 Increases Prostaglandin Release from Human Vascular SMC

\begin{tabular}{llrcl}
\hline Stimulus & Inhibitor & \multicolumn{1}{l}{$\mathrm{PGE}_{2}$} & \multicolumn{1}{c}{ 6-Keto-PGF ${ }_{1 \alpha}$} & \multicolumn{1}{l}{$\mathrm{PGF}_{2 \alpha}$} \\
\hline & & $n g / m l / 48 h$ & $n g / m l / 48 h$ & $n g / m l / 48 h$ \\
None & None & $0.6 \pm 0.1$ & $0.5 \pm 0.2$ & $0.4 \pm 0.1$ \\
& ASA & $0.4 \pm 0.1$ & $0.2 \pm 0.1$ & $0.3 \pm 0.1$ \\
& INDO & $0.4 \pm 0.1$ & $0.3 \pm 0.1$ & $0.3 \pm 0.1$ \\
rIL-1 $\alpha(1 \mathrm{ng} / \mathrm{ml})$ & None & $41.9 \pm 0.4$ & $16.1 \pm 2.3$ & $3.5 \pm 0.3$ \\
& ASA & $3.0 \pm 0.3$ & $1.2 \pm 0.2$ & $0.4 \pm 0.1$ \\
& INDO & $0.4 \pm 0.1$ & $0.1 \pm 0.1$ & $0.2 \pm 0.1$ \\
rIL-1 $\beta(10 \mathrm{ng} / \mathrm{ml})$ & None & $40.6 \pm 9.0$ & $21.3 \pm 0.6$ & $4.3 \pm 0.5$ \\
& ASA & $4.1 \pm 0.1$ & $1.5 \pm 0.4$ & $0.5 \pm 0.1$ \\
& INDO & $0.4 \pm 0.1$ & $0.2 \pm 0.1$ & $0.2 \pm 0.1$
\end{tabular}

Data are the means \pm SD of three observations; $S D<0.1$ are rounded up to 0.1. ASA (0.1 mM). INDO, Indomethacin $(1 \mu \mathrm{g} / \mathrm{ml})$.

DNA synthesis under some circumstances. Therefore, we also measured the accumulation of DNA by HSVSMC cultured with or without rIL-1 $\alpha$ or $\beta$ for $0-14 \mathrm{~d}$ in the presence of indomethacin $(1 \mu \mathrm{g} / \mathrm{ml})$. In this experiment, there was little or no net growth of the cultures incubated in medium that contained FCS alone at a suboptimal concentration $(5 \%)$ as determined by the DNA content measured in extracts (Fig. 2, triangles). Cultures incubated with the addition of either rIL-1 $\alpha$ (Fig. 2, open squares) or rIL-1 $\beta$ (Fig. 2, closed squares) accumulated DNA in a time-dependent manner. These phenomena were not limited to SMC of venous origin, as both rIL-1 $\alpha$ and $\beta$ in the presence of indomethacin increased TdR uptake by cultures of human aortic SMC prepared by collagenase dissociation (Table II).

IL-1-induced SMC growth does not depend on serumassociated mitogens. The foregoing experiments showed that IL-1 stimulated growth of cultured human vascular SMC. However, all of these experiments were performed in the pres-

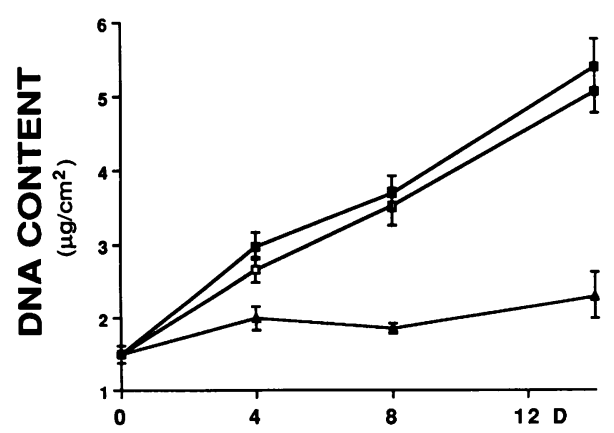

Figure 2. rIL-1 $\alpha$ or $\beta$ increases DNA accumulation in cultures of human vascular SMC. HSVSMC were incubated in 24-multiwell plates with DME containing FCS (5\%) alone (triangles) or with the addition of rIL-1 $\alpha(1 \mathrm{ng} / \mathrm{ml})$ (open squares), or $\mathrm{rIL}-1 \beta(10 \mathrm{ng} / \mathrm{ml}$ ) (closed squares), all in the presence of indomethacin $(1 \mu \mathrm{g} / \mathrm{ml})$. DNA content was determined at the outset of the experimental incubation and after 4,8 , or $14 \mathrm{~d}$. Data are mean \pm SD of six observations. 
Table II. IL-1 Stimulates Thymidine Incorporation by Human Aortic SMC

\begin{tabular}{lcl}
\hline & \multicolumn{2}{l}{$\left.{ }^{3} \mathrm{H}\right]$ Thymidine incorporation } \\
\cline { 2 - 3 } & - Indomethacin & + Indomethacin \\
\hline & $d p m /$ well $/ 24 \mathrm{~h}$ & $d p m /$ well $/ 24 \mathrm{~h}$ \\
Control $(\mathrm{FCS} \mathrm{5 \% )}$ & $2,752 \pm 415$ & $3,150 \pm 435$ \\
rIL-1 $\alpha(1 \mathrm{ng} / \mathrm{ml})$ & $1,325 \pm 334$ & $6,966 \pm 2,227$ \\
rIL-1 $\beta(10 \mathrm{ng} / \mathrm{ml})$ & $1,537 \pm 98$ & $7,064 \pm 911$
\end{tabular}

ence of FCS (5\%), which contains mitogens such as PDGF. Therefore, these experiments did not determine whether IL-1 potentiated PDGF or other serum-associated mitogens or could stimulate proliferation of HSVSMC in the absence of other growth factors. To address this issue we performed additional experiments that exposed HSVSMC cultures in parallel to rIL-1 $\alpha(1 \mathrm{ng} / \mathrm{ml})$ with or without indomethacin in a variety of medium supplements. As before, rIL-1 stimulated TdR incorporation by HSVSMC incubated with FCS ( 5 or $2 \%$ ) only in the presence of indomethacin (Fig. 3, crosshatched bars). In the absence of IL-1, the lower concentration of FCS (2\%) stimulated less TdR incorporation than did FCS (5\%) (Fig. 3, compare darkly and lightly crosshatched bars). Other conditions in this experiment used plasma-derived serum (PDS) prepared from horse blood and obtained commercially (HyClone Laboratories, Logan, UT). This material is prepared in a manner that limits the concentrations of coagulation-associated mitogens including PDGF (47). In pilot experiments this lot of PDS caused little or no growth of human or bovine vascular SMC, but supported the proliferation of bovine aortic SMC after the addition of highly purified PDGF (data not shown). Baseline measurements showed that PDS alone caused less TdR incorporation than did equivalent concentra-

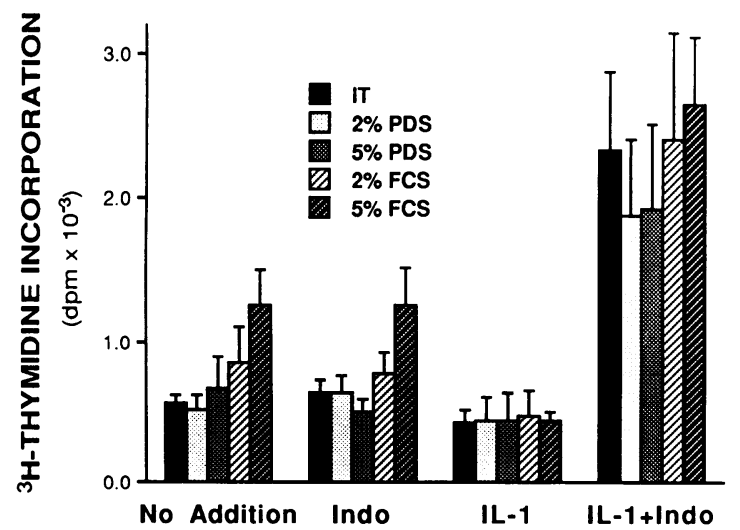

Figure 3. IL-1 stimulates TdR incorporation by human vascular SMC in the presence or absence of serum-associated mitogens. Cultures of HSVSMC in 96-multiwell plates were incubated in DME containing FCS ( 2 and 5\%), horse PDS ( 2 and 5\%), and in IT. The cell cultures were maintained in the various media without further addition, in the presence of indomethacin $(1 \mu \mathrm{g} / \mathrm{ml})$, with rIL- $1 \alpha(1$ $\mathrm{ng} / \mathrm{ml}$ ) alone, or in a combination of IL-1 and indomethacin for 48 h. Uptake of $\left[{ }^{3} \mathrm{H}\right] \mathrm{TdR}$ was measured during the second $24 \mathrm{~h}$ of this 2-d incubation. Data are mean \pm SD of eight observations. tions of FCS. rIL- $1 \alpha$ added to medium containing PDS ( 5 or $2 \%$ ) caused an approximately threefold increase in TdR incorporation in the presence of indomethacin (Fig. 3, stippled bars).

This experiment also evaluated the ability of rIL-1 to stimulate TdR incorporation in HSVSMC cultures incubated in serum-free chemically defined medium supplemented with insulin $(1 \mu \mathrm{M})$ and transferrin $(5 \mu \mathrm{g} / \mathrm{ml})(\mathrm{IT})$. rIL-1 stimulated $\mathrm{TdR}$ incorporation in the absence of any serum-associated mitogen (Fig. 3, solid bars). This finding shows that like PDGF, IL-1 stimulates cell proliferation in a simple medium that contains insulin or insulin-like factors $(47,48)$.

rIL-1s stimulate prostaglandin production by cultured human vascular SMC. IL-1 characteristically stimulates prostanoid production by target tissues. Several laboratories have found that monocyte-derived IL-1 increases prostaglandin production by vascular SMC (24-26). We tested the effects of rIL-1s on the release of prostaglandins by adult human vascular SMC (Table I). HSVSMC were incubated in 96-well plates in DME containing FCS (5\%) for $2 \mathrm{~d}$. Under basal conditions, these cells elaborated negligible amounts of $\mathrm{PGE}_{2}, 6-\mathrm{keto}$ $\mathrm{PGF}_{1 \alpha}$ (the stable metabolite of prostacyclin), or $\mathrm{PGF}_{2 \alpha}$, the major products of the cyclooxygenase pathway in vascular smooth muscle $(24,25)$. rIL- $1 \alpha$ or $\beta$ augmented the release of these prostanoids manyfold (Table I), at concentrations that stimulated TdR incorporation in an identical culture of these cells incubated in the presence of indomethacin (data not shown). The cyclooxygenase inhibitors, indomethacin (1 $\mu \mathrm{g} / \mathrm{ml}$ ) and aspirin (ASA, $0.1 \mathrm{mM}$ ), both inhibited the increases in prostaglandin production that were induced by IL-1 (Table I).

Prostaglandins induced by IL-1 inhibit the short-term mitogenic effect of this hormone on SMC. We hypothesized that rIL-1s failed to stimulate growth of HSVSMC because of simultaneous induction of the synthesis of growth-inhibitory prostanoids. To explore this possibility further we studied the relationship between the ability of rIL-1 to stimulate TdR incorporation by HSVSMC when prostanoid production was blocked to varying degrees. Indomethacin at $0.1 \mu \mathrm{g} / \mathrm{ml} \mathrm{com-}$ pletely prevented synthesis of $\mathrm{PGE}_{2}$ by IL-1-stimulated HSVSMC (Fig. 4, top). This concentration of indomethacin also maximally augmented $T d R$ incorporation in the same experiment. A concentration of indomethacin $(0.01 \mu \mathrm{g} / \mathrm{ml})$ that blocked $\mathrm{PGE}_{2}$ production incompletely permitted an intermediate rise in TdR incorporation in response to rIL-1 (Fig. 4 , top). Another inhibitor of cyclooxygenase, ASA, produced a similar pattern. Concentrations of ASA that incompletely inhibited $\mathrm{PGE}_{2}$ production also permitted only partial mitogenic response to rIL-1 (Fig. 4, bottom). The reciprocal relationship between TdR incorporation and prostanoid production in IL-1-stimulated HSVSMC, demonstrated by the effect of these two different cyclooxygenase inhibitors at varying concentrations, supports the concept that endogenous prostanoids limit the mitogenic response of HSVSMC to IL-1 in such experiments.

As an additional test for this hypothesis, we added exogenous prostanoids to HSVSMC incubated with IL- $1 \beta$ (10 $\mathrm{ng} / \mathrm{ml}$ ) in the presence of a concentration of indomethacin (1 $\mu \mathrm{g} / \mathrm{ml}$ ) that abolished endogenous prostanoid production. Both exogenous $\mathrm{PGE}_{1}$ and $\mathrm{PGE}_{2}$ (Sigma Chemical Co.) produced concentration-dependent inhibition of IL-1-induced 

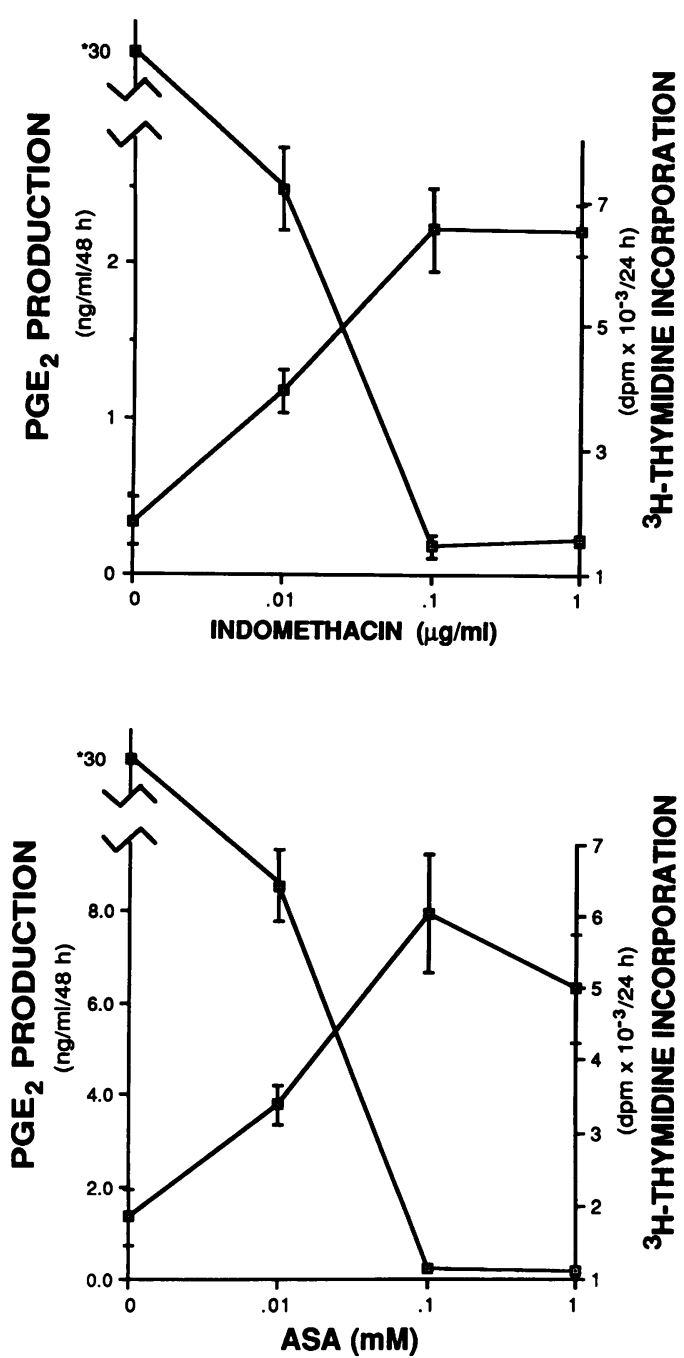

Figure 4. Inverse relationship between prostanoid production and TdR incorporation in human SMC cultures incubated with IL-1 in the presence of varying concentrations of cyclooxygenase inhibitors. HSVSMC cultures in 96-multiwell plates were incubated for $48 \mathrm{~h}$ in DME containing FCS (5\%) alone or in the presence of rIL-1 $\alpha(1.0$ $\mathrm{ng} / \mathrm{ml}$ ) with the indicated concentrations of either indomethacin or ASA. In one set of identical cultures, the medium was collected after $48 \mathrm{~h}$ and analyzed for $\mathrm{PGE}_{2}$ by radioimmunoassay $(a, n=3$, mean $\pm \mathrm{SD}$ ). The values marked by asterisks may be underestimated since these $\mathrm{PGE}_{2}$ measurements were at the upper limit of the assay. In parallel cultures, TdR incorporation was measured during the last $24 \mathrm{~h}$ of the 48 -h incubation ( $\square, n=8$, mean $\pm \mathrm{SD}$ ).

TdR incorporation (Fig. 5). The range of concentration of these prostanoids tested $(1-20 \mathrm{ng} / \mathrm{ml})$ corresponded to those actually produced by cultured HSVSMC stimulated by IL-1 (Table I, Fig. 4). An independent experiment with rIL-1 $\alpha$ yielded almost identical results (data not shown). In yet another similar experiment, $\mathrm{PGF}_{1 \alpha}$ and $\mathrm{PGF}_{2 \alpha}$ (both studied at $1-20 \mathrm{ng} / \mathrm{ml}$ ) did not inhibit IL-1-induced increases in TdR incorporation by indomethacin-treated HSVSMC (data not shown). This finding indicated that this inhibitory effect was most likely due to prostaglandins of the E series.

$I L-1$ produces morphologic changes and stimulates SMC growth even in the absence of cyclooxygenase inhibitors in longer-term experiments. The above experiments that exam-

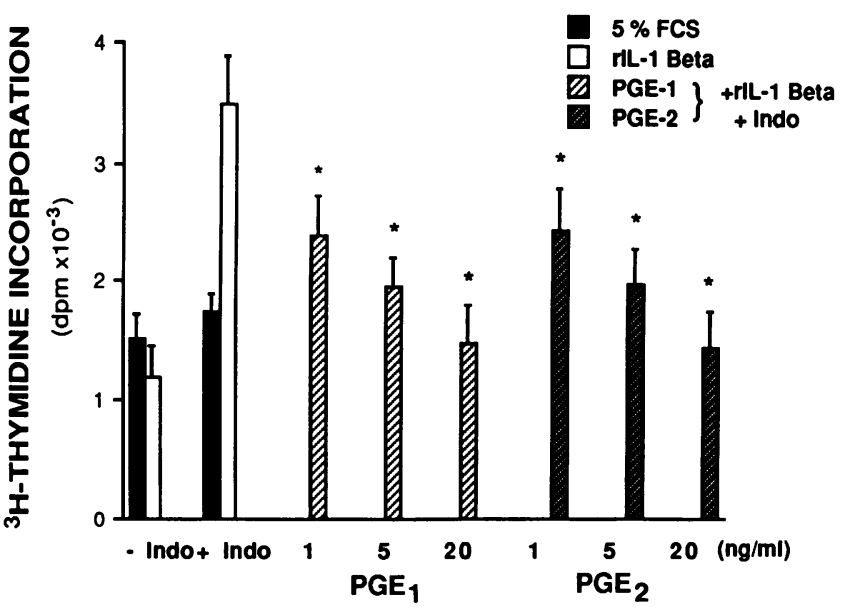

Figure 5. Exogenous PGEs inhibit the mitogenic effect of IL-1 on human vascular SMC. Cultures of HSVSMC in 96-well plates were incubated with DME containing FCS (5\%) and the indicated conditions for $48 \mathrm{~h}$. Thymidine incorporation was measured during the last $24 \mathrm{~h}$ of this $2-\mathrm{d}$ incubation. Prostaglandins were added at the indicated concentrations to cells incubated in medium that contained both $\mathrm{IL}-1 \beta(10 \mathrm{ng} / \mathrm{ml})$ and indomethacin. The asterisks indicate a statistically significant difference $(P<0.01$; Student's $t$ test, $n=8)$ compared with rIL- $1 \beta$ in the presence of indomethacin (the condition represented by the taller of the two open bars).

ined the effect of cyclooxygenase inhibitors on SMC growth were limited to 48 -h incubations. We also determined the effect of rIL-1 on cell morphology and growth in longer-term experiments with or without indomethacin. In preliminary experiments, we were surprised to find that after $1 \mathrm{wk}$ of exposure to rIL-1 $\alpha$ or $\beta$, cultures of HSVSMC showed significant alterations in the pattern and extent of growth even in the absence of indomethacin (data not shown). Therefore, we studied the effect of rIL- $1 \alpha(1$ and $10 \mathrm{ng} / \mathrm{ml})$ on the morphology and growth of HSVSMC incubated in FCS (5\%) without cyclooxygenase inhibitors over a 4-wk-period. Over the first several days phase-contrast microscopy revealed little or no difference in cellular morphology under these various conditions (data not shown). After 4 or $5 \mathrm{~d}$ of exposure to rIL-1 $\alpha$, the cells assumed a more bipolar, spindle-shaped appearance (Fig. $6, A-C)$. At this time cells incubated with either concentration of rIL-1 $\alpha$ showed numerous mitotic figures compared with cultures incubated in FCS (5\%) alone (compare Fig. $6 A$ to $6 B$ or $6 C$ ). Phase-contrast microscopy continued to reveal evidence of increased cell proliferation in the cultures exposed to rIL- $1 \alpha$ as seen by luxuriant multilayer and whorl formation visible after $1 \mathrm{wk}$ and continuing for up to $4 \mathrm{wk}$ of continued exposure (Fig. 6, $D-F$ ). Montesano et al. (49) observed similar elongation and whorl formation in human fetal endothelial cell cultures exposed to monocyte-derived IL-1. We have also found that rIL-1s produce such morphologic changes in adult human endothelial cell cultures. However, we have so far failed to demonstrate a mitogenic effect of IL-1 on human endothelial cells, even when cultured in the presence of indomethacin (data not shown).

After more than a week or so in culture, microscopy was no longer necessary to observe the abundance of cellular material in the IL-1-treated cultures. Inspection of the unmagnified cell layer through the bottom of the culture dish or during medium 

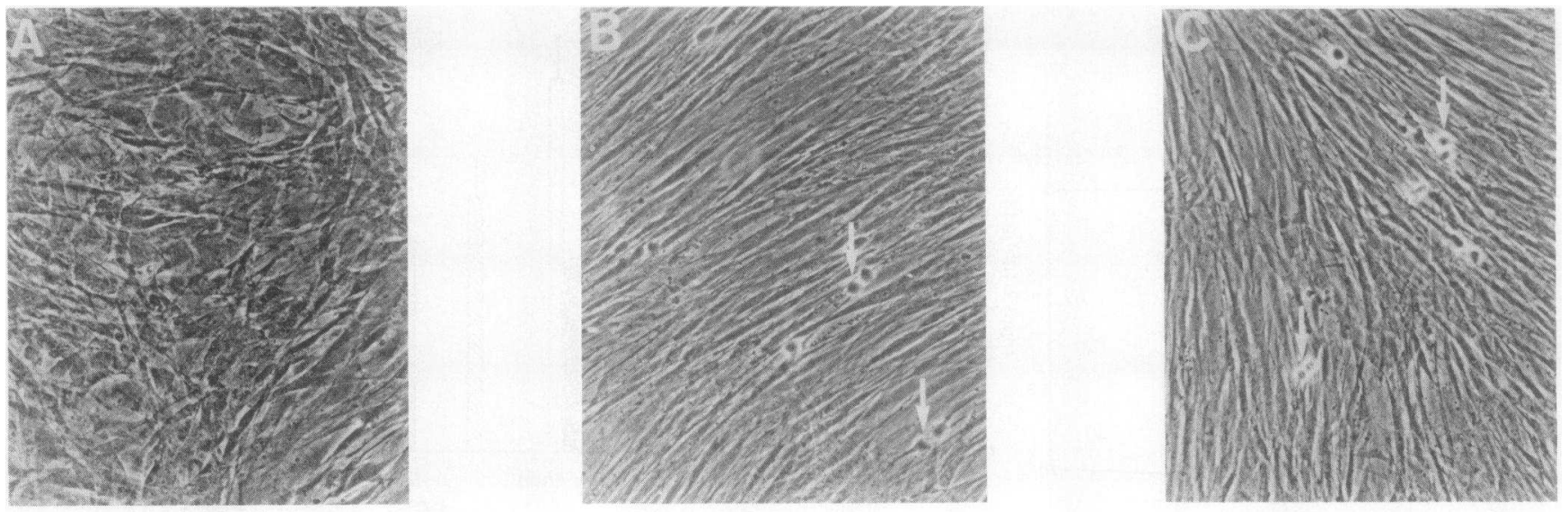

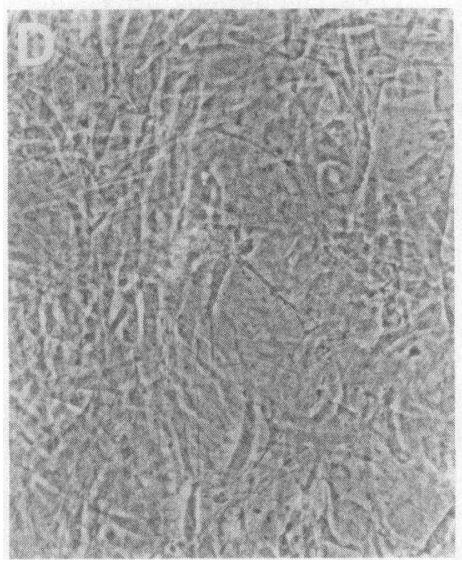

Figure 6. Incubation with rIL-1 alters the morphology and growth pattern of cultured human vascular SMC. Replicate cultures of HSVSMC in 12-multiwell plates were incubated in DME with FCS (5\%) alone $(A$ and $D)$ or in the presence of $\operatorname{rlL}-1 \alpha$ at $1 \mathrm{ng} / \mathrm{ml}(B$ and $E$ ) or $10 \mathrm{ng} / \mathrm{ml}(C$ and $F)$. After $5 \mathrm{~d}(A-C)$ the IL-1-treated SMC appeared elongated and bipolar by phase-contrast microscopy. There

changes showed this accumulation macroscopically. At the end of this 4-wk experiment amido black staining confirmed these observations (Fig. 7, $B$ and $C$ ). Spectrophotometric quantitation of the amount of dye bound by these cell layers showed a fivefold increase in binding of the dye by the IL-1treated cell layers (Fig. 7, graph). Amido black probably stains the cell layer by binding to both intra- and extracellular proteins. This procedure may actually underestimate the amount of protein in the overgrown IL-1-treated wells because the dye may not have equal access to all cells in the multilayers characteristically formed by SMC in dense cultures. Note that in both the 2-d (Fig. $1 \mathrm{~A}$ ) and 28-d (Figs. 6 and 7) experiments 1 $\mathrm{ng} / \mathrm{ml}$ of rIL- $1 \alpha$ produced nearly as great an effect as a five- to tenfold higher concentration on all variables studied.

Comparison of the mitogenic effects of IL-1 and PDGF on human vascular SMC in culture. PDGF is the prototypical smooth muscle mitogen and accounts for much of the growth-promoting activity found in serum. PDGF has been highly purified from human platelets, and it was of interest to compare the mitogenic effects of PDGF and IL-1 on were frequent mitotic figures (white arrows). After $28 \mathrm{~d}$ of incubation $(D-F)$ the cells maintained in DME with FCS alone retained their polygonal morphology while the cultures maintained in rIL-1 $\alpha(E$ and $F$ ) show marked accentuation of the morphologic changes that were already observed after $5 \mathrm{~d}$. It was difficult to focus on a single plane in these latter conditions as there were many layers of cells.

HSVSMC. PDGF produced near maximal increases in TdR incorporation at $5 \mathrm{ng} / \mathrm{ml}$ (Fig. 8). The addition of indomethacin resulted in only a small increment in TdR incorporation under these conditions. IL- $1 \alpha$ produced a near maximal effect at $10 \mathrm{ng} / \mathrm{ml}$ in the presence of indomethacin (Fig. 8). In the absence of indomethacin, IL-1 did not stimulate TdR incorporation. The failure of indomethacin to increase significantly the mitogenic effect of PDGF may be because this mitogen does not induce $\mathrm{PGE}_{1}$ or $\mathrm{PGE}_{2}$ release by HSVSMC. Two independent experiments showed no $\mathrm{PGE}_{2}$ production by these cells during a 48-h incubation with PDGF $(0.1-5 \mathrm{ng} / \mathrm{ml})$ (data not shown).

Studies with selective antibodies suggest that the mitogenic effects of IL-1 and PDGF on human vascular SMC are independent. Under some circumstances SMC themselves can express PDGF genes and secrete PDGF like growth-promoting activity (50-53). It was possible that IL-1 stimulated SMC proliferation indirectly by inducing endogenous PDGF production. We tested whether release of immunoreactive PDGF contributed to the IL-1-induced growth of HSVSMC in ex- 

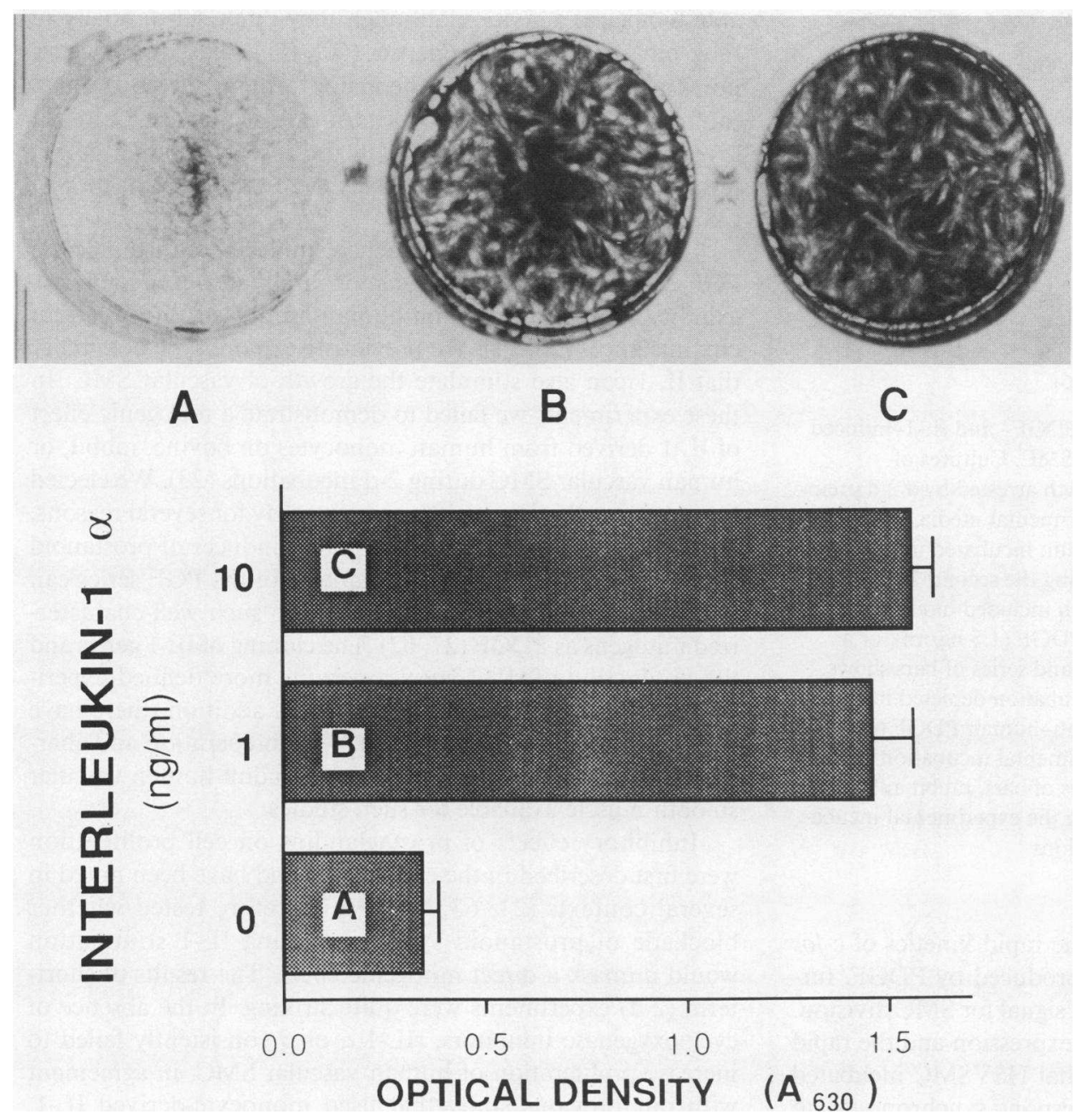

Figure 7. Prolonged incubation with rIL-1 markedly alters the growth of human vascular SMC. The same cell layers presented in Fig. 6 were stained with amido black and photographed after the 28-d incubation. Condition A contained FCS alone, condition B contained rIL-1 $\alpha$ (1 $\mathrm{ng} / \mathrm{ml}$ ), and condition $\mathrm{C}$ contained rIL-1 $\alpha(10 \mathrm{ng} / \mathrm{ml})$. Note the macroscopic changes in conditions $B$ and $C$ that corresponded to the phase microscopic observations presented in Fig. 6, $E$ and $F$. The bar graph beneath the photograph shows the amido black binding determined in extracts of these same cell layers. Data are mean $\pm S D$ of three observations. periments that used antibodies that selectively neutralized these two hormones. In the absence of added antibody, submaximal growth-promoting concentrations of both IL- $1 \alpha(1$

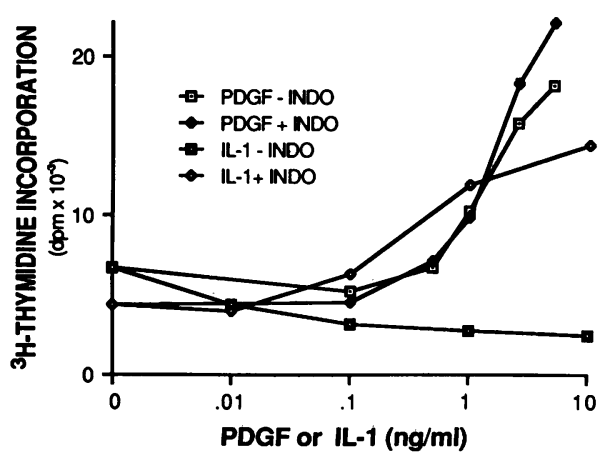

Figure 8. Comparison of the effects of PDGF and IL-1 on TdR incorporation by HSVSMC. Cultures of HSVSMC in 96-multiwell plates were preincubated in IT for $48 \mathrm{~h}$ to arrest cell growth and to deplete any available serum-associated PDGF. The medium was then replaced with fresh IT that contained the indicated concentrations of rIL-1 $\alpha$ or PDGF highly purified from human platelets. Thymidine incorporation was measured during the second $24 \mathrm{~h}$ of a 48-h incubation in the presence or absence of indomethacin $(1 \mu \mathrm{g} / \mathrm{ml})$. Data are mean of eight observations. $\mathrm{ng} / \mathrm{ml})$ and PDGF $(1.5 \mathrm{ng} / \mathrm{ml})$, in the presence of indomethacin $(1 \mu \mathrm{g} / \mathrm{ml})$, stimulated TdR incorporation by HSVSMC. In combination, PDGF and IL-1 produced additive effects (Fig. 9). Addition of monospecific anti-human PDGF IgG completely inhibited the stimulatory effect of PDGF on TdR incorporation, but did not block the effect of IL-1 either alone or in the presence of added PDGF. In contrast, addition of anti-IL$1 \alpha$ IgG completely blocked the mitogenic effect of the interleukin, but did not affect the stimulatory effect of PDGF (Fig. 9). The results of these antibody inhibition experiments support an effect of IL-1 on smooth muscle growth that is independent of mediation by release of immunoreactive PDGF.

$I L-1$ rapidly and transiently induces expression of the c-fos proto-oncogene in vascular SMC. Addition of PDGF or fresh serum to fibroblasts or SMC rapidly induces mRNA that encodes the c-fos proto-oncogene. The product of this gene is a protein associated with the cell nucleus that may be involved in signaling the early events in commitment to cell division (54-57). If IL-1 were a mitogen for SMC, it should induce this proto-oncogene. Northern blotting experiments did not reveal c-fos transcript in RNA isolated from unstimulated HSVSMC. 15 min after addition of IL-1, c-fos mRNA was detected, and maximal levels were observed one-half hour after addition of the cytokine (Fig. 10). By $3 \mathrm{~h}$, c-fos mRNA was again undetected. Note that PDGF modulated levels of c-fos mRNA with 


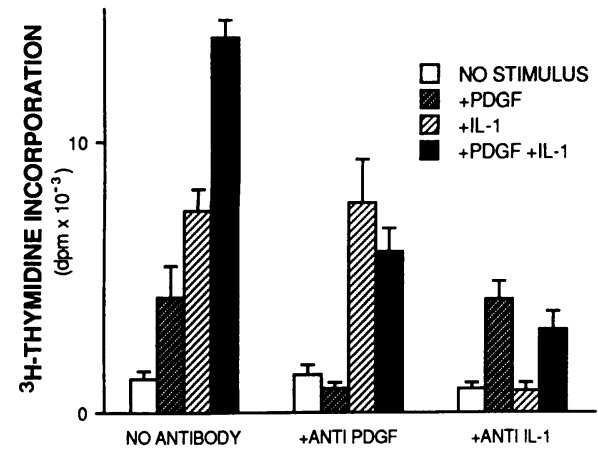

Figure 9. Effect of selective antibodies on PDGF- and IL-1-induced stimulation of TdR incorporation by HSVSMC. Cultures of HSVSMC in 96-multiwell plates were growth arrested by a $2 \mathrm{~d}$ preincubation in IT before the addition of experimental media, which was also compounded in this serum-free medium, incubated for $48 \mathrm{~h}$, and TdR incorporation was measured during the second $24 \mathrm{~h}$ of this incubation. The experimental media, which included indomethacin $(1 \mu \mathrm{g} / \mathrm{ml})$, contained $\mathrm{rIL}-1 \alpha(1 \mathrm{ng} / \mathrm{ml})$ or PDGF $(1.5 \mathrm{ng} / \mathrm{ml})$, or a combination of both hormones. The left-hand series of bars shows data obtained without antibody. In the incubation depicted in the middle series of bars, monospecific goat anti-human PDGF (100 $\mu \mathrm{g} / \mathrm{ml}$ ) was included throughout the experimental incubation. In the incubation depicted in the right-hand series of bars, rabbit antihuman IL- $1 \alpha(5 \mu \mathrm{g} / \mathrm{ml})$ was present during the experimental incubation. Data are mean \pm SD of eight observations.

an identical time course (Fig. 10). The rapid kinetics of c-fos induction by IL-1, identical to that produced by PDGF, further supports a direct role for IL-1 as a signal for SMC division. In addition, the lack of baseline c-fos expression and the rapid rise and fall of this mRNA indicate that HSVSMC incubated in IT are indeed growth arrested and respond synchronously to added mitogens.

\section{Discussion}

Proliferation of mesenchymal cells such as fibroblasts and smooth muscle contributes to fibrogenesis in wound healing as well as in certain important pathological processes. In the lung such mesenchymal cell multiplication occurs in interstitial fibrosis and granulomatous diseases (21). An analogous situation may occur in some types of hepatic fibrosis (58). Certain glomerulopathies also involve proliferative lesions (59). In the context of the blood vessel, multiplication of vascular SMC is a key component in formation of the complicated atherosclerotic plaque (1-3). This process may also play a role in the structural changes in blood vessels that may help sustain or contribute to progression of both systemic and pulmonary hypertension (2).

The presence of phagocytic leukocytes characterizes the early stages of the lesions in several of these pathological situations. Activated mononuclear cells are a likely source of mediators that signal cellular proliferation and the synthesis of macromolecules that contribute to fibrogenesis. PDGF-like mitogens account for part of the growth-promoting activity for mesenchymal cells produced by human macrophages (14-16). Another candidate is IL-1, a major secretory product of activated human monocytes. These cells express two distinct genes that encode protein products that have virtually indistinguish- able biological activities, although they differ substantially in their physicochemical properties (60). IL-1 $\beta$ has an isoelectric point near neutrality and is the major form secreted by human monocytes upon activation; its message may account for several percent of the mRNA in these cells (28). The other less abundant species, IL- $1 \alpha$, has an isoelectric point of $\sim 5$ $(29,30)$.

IL- $1 \beta$ has a degree of sequence similarity with the acidic FGF/endothelial cell growth factor family $(22,61)$, and IL-1 exhibits mitogenic effects on human fibroblasts under certain circumstances $(20,21)$. We previously explored the possibility that IL-1 can also stimulate the growth of vascular SMC. In these experiments we failed to demonstrate a mitogenic effect of IL-1 derived from human monocytes on bovine, rabbit, or human vascular SMC during 2-d incubations (23). We elected to reexamine this issue in the current study for several reasons. It is now apparent that IL-1 is a potent inducer of prostanoid synthesis in SMC, and that prostanoids of the PGE series can inhibit the response of vascular SMC to such well-characterized mitogens as PDGF $(27,62)$. The cloning of IL-1 genes and the production of rIL-1 species permits more defined experiments than were previously possible. In addition, there have been considerable improvements in the preparation and characterization of preparations of cultured adult human vascular smooth muscle available for such studies.

Inhibitory effects of prostaglandins on cell proliferation were first described in the early 1970s and have been noted in several contexts $(21,63,64)$. We therefore tested whether blockade of prostanoid synthesis during IL-1 stimulation would unmask a direct mitogenic effect. The results of shortterm ( $2 \mathrm{~d})$ experiments were quite striking. In the absence of cyclooxygenase inhibitors, rIL- $1 \alpha$ or $\beta$ consistently failed to increase proliferation of human vascular SMC, in agreement with our previous study that used monocyte-derived IL-1. However, indomethacin or aspirin, which produced concentration-dependent inhibition of prostanoid synthesis by IL-1stimulated HSVSMC, increased TdR incorporation by these cells. The concentration dependence of these two reciprocal effects was identical (Fig. 4, $A$ and $B$ ). Addition of exogenous $\mathrm{PGE}_{1}$ or $\mathrm{PGE}_{2}$ to IL-1-stimulated HSVSMC, treated with indomethacin to block endogenous prostanoid synthesis, inhibited the mitogenic effect of rIL-1 (Fig. 5). Although the antibody we used to measure $\mathrm{PGE}$ recognized $\mathrm{PGE}_{1}$ as well as $\mathrm{PGE}_{2}$, since both of these compounds inhibit IL-1-induced SMC proliferation, this distinction is not critical to the interpretation of our findings. Thus, our data are consistent with a direct stimulatory effect of IL-1 on human vascular SMC growth that is counterbalanced in the short term by an "autocrine" inhibitory loop that involves prostaglandins.

Exposure of HSVSMC to rIL-1 for longer periods (1-4 wk) caused growth of HSVSMC even in the absence of cyclooxygenase inhibitors. The present data do not distinguish between several possible mechanisms for this "escape" phenomenon. The prolonged exposure of HSVSMC to rIL-1 could result in reduced production or responsiveness to prostaglandin. However, preliminary measurements showed that HSVSMC treated with IL-1 from 2 to $8 \mathrm{~d}$ continued to release $\mathrm{PGE}_{2}$ (data not shown). The apparent disparity between the acute experiments that involve primarily TdR uptake measurements and the longer-term experiments might also reflect a selective effect of prostaglandins on TdR uptake or the specific activity of the 
IL-1 $\beta$

\section{c-fos}

$28 S>$

$18 S>$

$\begin{array}{lllll}0 & 15^{\prime} 30^{\prime} & 1 & 3 & 6 h\end{array}$

\section{$\beta$-tubulin}

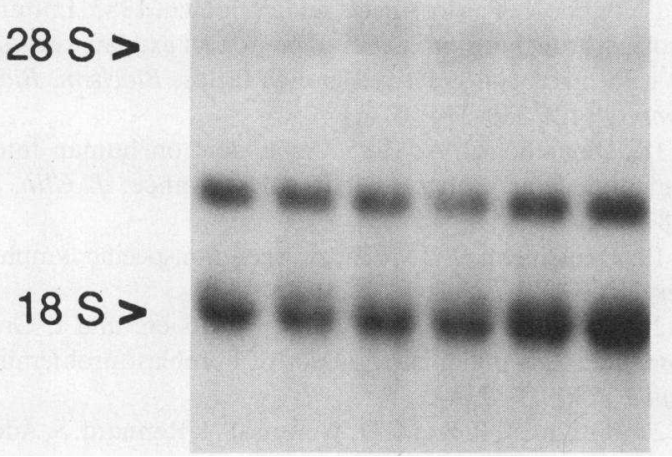

PDGF

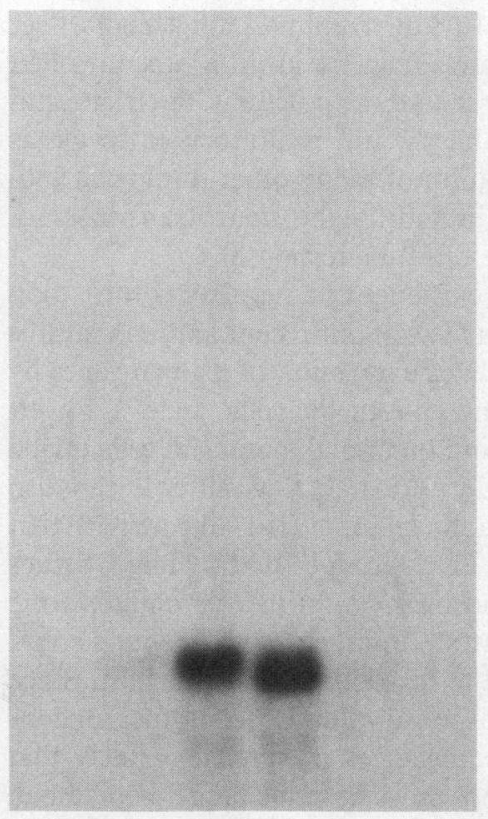

$\begin{array}{lllll}0 & 15^{\prime} 30^{\prime} & 1 & 3 & 6 h\end{array}$

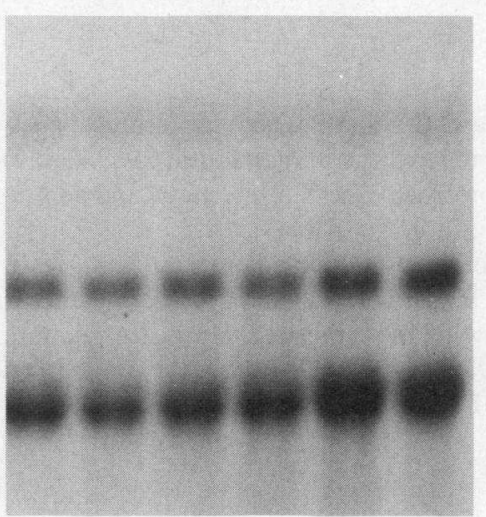

Figure 10. IL-1 and PDGF rapidly and transiently increase steady state levels of c-fos mRNA in adult human vascular SMC. Cultures of HSVSMC in Petri plates ( $15 \mathrm{~cm}$ diam) were washed with Hanks' balanced salt solution, and growth arrested by maintenance for $24 \mathrm{~h}$ in IT.

Cultures were then incubated for the indicated times in IT with indomethacin $(1 \mu \mathrm{g} / \mathrm{ml})$ that contained rIL- $\beta$ ( 10 $\mathrm{ng} / \mathrm{ml}$ ) or PDGF purified from human platelets (1 $\mathrm{ng} / \mathrm{ml}$ ). At the end of each experimental incubation, the medium was removed and the cell layer was immediately dissolved in cold guanidinium isothiocyanate solution. RNA was isolated by centrifugation through cesium chloride. Northern analysis, transfer, fixation, and hybridization were performed as previously described $(32$, 38). The top shows an autoradiogram resulting from hybridization of the membrane with v-fos proviral DNA nick translated to a specific activity of $1.5 \times 10^{9} \mathrm{cpm} / \mu \mathrm{g}$ DNA. The autoradiogram shown was exposed for 5 d. The bottom shows the result of a rehybridization of the same northern blot

with the probe for the constitutively expressed form of $\beta$-tubulin, nick translated to a specific activity of $9 \times 10^{8} \mathrm{cpm} / \mu \mathrm{g} \mathrm{DNA}$. This exposure was for $1 \mathrm{~d}$. The size markers (arrowheads) are the positions of migration of the 18- and 28-S ribosomal RNA subunits.

TdR precursor pool for DNA synthesis. However, rIL-1 caused small but significant net increases in DNA content in indomethacin-treated cells over a 2-d period (data not shown). Also, Nilsson and Olsson (27) showed that $\mathrm{PGE}_{1}$ or $\mathrm{PGE}_{2}$ reduced the fraction of nuclei labeled with tritiated $T d R$ in PDGF-treated rat SMC, an effect unlikely to be due to altered TdR transport or pool specific activity. Bitterman et al. (21) also documented that $\mathrm{PGE}_{2}$ reduced labeling indices of fibronectin-stimulated fibroblasts.

Factors that regulate cell growth appear to act by a variety of mechanisms. Certain "growth factors" such as PDGF or FGF render cells competent to enter $\mathrm{S}$ phase. Other factors (e.g., insulin-like growth factor-I or somatomedin) do not themselves signal entry of the cells into $S$ phase, but permit cells prepared for division by other signals to progress through the cell cycle $(65,48)$. High concentrations of insulin such as those used in the defined serum-free medium denoted IT (Fig. 7) are not themselves mitogenic for SMC, but may act like somatomedin (40). Thus, these results indicate that rIL-1 prepares SMC for entry into the cell cycle in a manner analogous to PDGF. The ability of IL-1 to increase c-fos mRNA levels rapidly and transiently in SMC provides further evidence that this cytokine may trigger early events in the commitment process for cell division. IL-1 and PDGF increased c-fos mRNA with similar kinetics (Fig. 10). Our experiments also show that the potency of IL-1 both in promoting growth of HSVSMC and in modulating c-fos message level is of the same order of magnitude as PDGF (Figs. 8-10).

The results of these studies highlight the potential complexity of growth control in the blood vessel wall. In addition to positive stimuli such as PDGF, IL-1, and other mitogens, the regulation of SMC growth probably includes inhibitory 
loops that involve prostanoids or heparin-like molecules (66). Since IL-1 induces prostaglandin synthesis by mesenchymal cells this hormone can stimulate both positive and negative limbs of growth control. In intact animals, this dual effect would have the obvious advantage of limiting uncontrolled cell proliferations in response to these mitogens. Such simultaneous induction of stimulatory and inhibitory pathways is common in the fine regulation of many other important biological systems in vivo, including the neurotransmission, blood coagulation, and the immune response.

In the case of IL-1, the existence of a negative control loop is particularly significant in view of our recent finding that this family of hormones stimulates expression of its own genes by vascular smooth muscle and endothelial cells $(26,67)$. Lovett and colleagues $(68,69)$ found that renal mesangial cells divide in response to monocyte-derived IL-1; this cell type can also express an IL-1 gene (70) and elaborate IL-1-like activity that stimulates its own growth. Production of IL-1 by target tissues such as smooth muscle and mesangium in vivo could set the stage for an autostimulatory inflammatory response that would amplify and extend to the detriment of the host. Since the local inflammatory response seldom propagates uncontrolled under normal circumstances in vivo, it is likely that such inhibitory control loops as we describe here do operate in the intact organism to modulate this response and limit positive feedback situations.

\section{Acknowledgments}

We thank Maria W. Janicka and Cynthia B. Galin for technical assistance. Dr. Louis K. Birinyi prepared the human aortic SMC used in this study. Joan L. Leonard provided excellent secretarial and administrative assistance.

These studies were supported by a grant from National Heart, Lung, and Blood Institute to P. Libby (HL34636). S. J. C. Warner is the Samuel A. Levine Fellow of the American Heart Association, Massachusetts Affiliate, for 1986-1987, and P. Libby is an Established Investigator of the American Heart Association.

\section{References}

1. Haust, M. D., R. H. More, and H. Z. Movat. 1960. The role of smooth muscle cells in the fibrogenesis of arteriosclerosis. Am. J. Pathol. 37:377-389.

2. Gordon, D., and S. M. Schwartz. 1987. Replication of arterial smooth muscle cells in hypertension and atherosclerosis. Am. J. Cardiol. 59:44A-48A.

3. Ross, R., and J. A. Glomset. 1976. The pathogenesis of atherosclerosis. N. Engl. J. Med. 295:369-377, 420-425.

4. Ross, R. 1986. The pathogenesis of atherosclerosis: an update. $N$. Engl. J. Med. 314:488-500.

5. Poole, J. C. F., and H. W. Florey. 1958. Changes in the endothelium of the aorta and the behaviour of macrophages in experimental atheroma of rabbits. J. Pathol. Bacteriol. 75:245-253.

6. Gerrity, R. G., H. K. Naito, M. Richardson, and C. J. Schwartz. 1979. Dietary induced atherogenesis in swine: morphology of the intima in prelesion stages. Am. J. Pathol. 95:775-786.

7. Fowler, S., H. Shio, and N. J. Haley. 1979. Characterization of lipid-laden aortic cells from cholesterol-fed rabbits. IV. Investigation of macrophage-like properties of aortic cell populations. Lab. Invest. 41:372-378.

8. Joris, I., T. Zand, J. J. Nunnari, F. J. Krolikowski, and G. Majno. 1983. Studies on the pathogenesis of atherosclerosis. I. Adhesion and emigration of mononuclear cells in the aorta of hypercholesterolemic rats. Am. J. Pathol. 113:341-358.

9. Faggioto, A., R. Ross, and L. Harker. 1984. Studies of hypercholesterolemia in the nonhuman primate. I. Changes that lead to fatty streak formation. Arteriosclerosis. 4:323-340.

10. Fowler, S., P. A. Berberian, H. Shio, G. Goldfischer, and H. Wolinsky. 1980. Characterization of cell populations isolated from aortas of rhesus monkeys with experimental atherosclerosis. Circ. Res. 46:520-530.

11. Faggioto, A., and R. Ross. 1984. Studies of hypercholesterolemia in the nonhuman primate. II. Fatty streak conversion to fibrous plaque. Arteriosclerosis. 4:341-356.

12. Leibovich, S. J., and R. Ross. 1976. A macrophage-dependent factor that stimulates the proliferation of fibroblasts in vitro. Am. J. Pathol. 84:501-514.

13. Martin, B. M., M. A. Gimbrone, Jr., E. R. Unanue, and R. S. Cotran. 1981. Stimulation of nonlymphoid mesenchymal cell proliferation by a macrophage-derived growth factor. J. Immunol. 126:15101515.

14. Shimokado, K., E. W. Raines, D. K. Madtes, T. B. Barrett, E. P. Benditt, and R. Ross. 1985. A significant part of macrophage-derived growth factor consists of at least two forms of PDGF. Cell. 43:277-286.

15. Martinet, Y., P. B. Bitterman, J. F. Mornex, G. R. Grotendorst, G. R. Martin, and R. G. Crystal. 1986. Activated human monocytes express the c-sis proto-oncogene and release a mediator showing PDGF-like activity. Nature (Lond.). 319:158-160.

16. Martinet, Y., H. A. Jaffe, K. Yamauchi, C. Betsholtz, B. Westermark, C. H. Heldin, and R. G. Crystal. 1987. Platelet-derived growth factor (PDGF) $\beta$-chain gene expression by activated blood monocytes precedes the expression of the PDGF A-chain gene. Fed. Proc. 46:1996. (Abstr.)

17. Baird, A., P. Moremede, and P. Bohlen. 1985. Immunoreactive fibroblast growth factor in cells of peritoneal exudate suggests its identity with macrophage-derived growth factor. Biochem. Biophys. Res. Commun. 126:358-364.

18. Dinarello, C. A. 1985. An update on human interleukin-1: from molecular biology to clinical relevance. J. Clin. Immunol. 5:287-297.

19. Oppenheim, J. J. 1985. Antigen nonspecific lymphokines: an overview. Methods Enzymol. 116:357-372.

20. Schmidt, J. A., S. B. Mizel, D. Cohen, and I. Green. 1982. Interleukin 1, a potential regulator of fibroblast proliferation. J. Immunol. 128:2177-2182.

21. Bitterman, P. B., M. D. Wewers, S. I. Rennard, S. Adelberg, and R. G. Crystal. 1986. Modulation of alveolar macrophage-driven fibroblast proliferation by alternative macrophage mediators. J. Clin. Invest. 77:700-708.

22. Thomas, K. A., M. Rios-Candelore, G. Gimenez-Gallego, J. DiSavlo, C. Bennett, J. Rodkey, and S. Fitzpatrick. 1985. Pure brainderived acidic fibroblast growth factor is a potent angiogenic vascular endothelial cell mitogen with sequence homology to interleukin 1. Proc. Natl. Acad. Sci. USA. 82:6409-6413.

23. Libby, P., D. J. Wyler, M. W. Janicka, and C. A. Dinarello. 1985. Differential effects of human interleukin-1 on growth of human fibroblasts and vascular smooth muscle cells. Arteriosclerosis. 5:186191.

24. Rossi, V., F. Breviario, P. Ghezzi, E. Dejana, and A. Mantovani. 1985. Prostacyclin synthesis induced in vascular cells by interleukin-1. Science (Wash. DC). 229:174-176.

25. Albrightson, C. R., N. L. Baenziger, and P. Needleman. 1985. Exaggerated human vascular cell prostaglandin biosynthesis mediated by monocytes: role of monokines and interleukin 1. J. Immunol. 135:1872-1877.

26. Warner, S. J. C., K. R. Auger, and P. Libby. 1987. Human interleukin-1 induces interleukin-1 gene expression in human vascular smooth muscle cells. J. Exp. Med. 165:1316-1331.

27. Nilsson, J., and A. G. Olsson. 1984. Prostaglandin $E_{1}$ inhibits 
DNA synthesis in arterial smooth muscle cells stimulated with platelet-derived growth factor. Atherosclerosis. 53:77-82.

28. Auron, P. E., A. C. Webb, L. J. Rosenwasser, S. F. Mucci, A. Rich, S. M. Wolff, and C. A. Dinarello. 1984. Nucleotide sequence of human monocyte interleukin-1 precursor cDNA. Proc. Natl. Acad. Sci. USA. 81:7907-7911.

29. March, C. J., B. Mosley, A. Larsen, D. P. Cerretti, G. Braedt, V. Price, S. Gillis, C. S. Henney, S. R. Kronheim, K. Grabstein, P. J. Conlon, T. P. Hopp, and D. Cosman. 1985. Cloning, sequence and expression of two distinct human interleukin-1 complementary DNAs. Nature (Lond.). 315:641-647.

30. Gubler, U., A. O. Chua, A. S. Stern, C. P. Hellman, M. P. Vitek, T. M. Dechiara, W. R. Benjamin, K. J. Collier, M. Dukovich, P. C. Familetti, C. Fiedler-Nagy, J. Jenson, K. Kaffka, P. L. Kilian, D. Stremlo, B. H. Wittreich, D. Woehle, S. B. Mizel, and P. T. Lomedico. 1986. Recombinant human interleukin $1 \alpha$ : purification and biological characterization. J. Immunol. 136:2492-2497.

31. Ross, R., and B. Kariya. 1980. Morphogenesis of vascular smooth muscle in atherosclerosis and cell structure. In Handbook of Physiology: The Cardiovascular System. 2. D. F. Bohr, A. P. Somlyo, and H. Y. Sparks, editors. American Physiological Society, Bethesda, MD. 69-91.

32. Libby, P., J. M. Ordovàs, L. K. Birinyi, K. R. Auger, and C. A. Dinarello. 1986. Inducible interleukin 1 gene expression in human vascular smooth muscle cells. J. Clin. Invest. 78:1432-1438.

33. Tsukada, T., D. Tippens, D. Gordon, R. Ross, and A. M. Gown. 1987. HHF35, a muscle-actin-specific monoclonal antibody. Am. J. Pathol. 127:51-60.

34. Gunther, S., R. W. Alexander, W. J. Atkinson, and M. A. Gimbrone, Jr. 1982. Functional angiotensin II receptors in cultured vascular smooth muscle. J. Cell Biol. 92:289-298.

35. Dinarello, C. A., J. G. Cannon, J. W. Mier, H. A. Bernheim, G. LoPreste, D. L. Lynn, R. N. Love, A. C. Webb, P. E. Auron, R. C. Reuben, A. Rich, S. M. Wolff, and S. D. Putney. 1986. Multiple biological activities of human recombinant interleukin 1. J. Clin. Invest. 77:1734-1739.

36. Raines, E. W., and R. Ross. 1982. Platelet-derived growth factor. I. High yield purification and evidence for multiple forms. J. Biol. Chem. 25:5154-5160.

37. van Straaten, R., R. Muller, T. Curran, C. van Beveren, and I. M. Verma. 1983. Complete nucleotide sequence of a human c-onc gene: deduced amino acid sequence of the human c-fos protein. Proc. Natl. Acad. Sci. USA. 80:3183-3187.

38. Libby, P., J. M. Ordovas, K. R. Auger, A. H. Robbins, L. K. Birinyi, and C. A. Dinarello. 1986. Endotoxin and tumor necrosis factor induce interleukin- 1 beta gene expression in adult human vascular endothelial cells. Am. J. Pathol. 124:179-185.

39. Bond, J. F., and S. R. Farmer. 1983. Regulation of tubulin and actin mRNA production in rat brain: expression of a new beta-tubulin mRNA with development. Mol. Cell. Biol. 3:1333-1342.

40. Libby, P., and K. V. O'Brien. 1983. Culture of quiescent vascular smooth muscle cells in a defined serum-free medium. J. Cell. Physiol. 115:217-223.

41. Cesarone, C. F., C. Bolognesi, and L. Santi. 1979. Improved microflurometric DNA determination in biologic material using 33258 Hoechst. Anal. Biochem. 100:188-197.

42. Vilček, J., V. J. Palombella, D. Henriksen-DeStefano, C. Swenson, R. Feinman, M. Hirai, and M. Tsujimoto. 1986. Fibroblast growth enhancing activity of tumor necrosis factor and its relationship to other polypeptide growth factors. J. Exp. Med. 163:632-643.

43. Gimbrone, M. A., Jr., and R. W. Alexander. 1977. Prostaglandin production by vascular endothelial and smooth muscle cells in culture. In Prostaglandins in Hematology. M. J. Silver, J. B. Smith, and J. J. Kocsis, editors. Spectrum Publications, New York. 121-134.

44. Coughlin, S. R., M. A. Moskowitz, H. N. Antoniades, and L. Levine. 1981. Serotonin receptor-mediated stimulation of bovine smooth muscle cell prostacyclin synthesis and its modulation by platelet-derived growth factor. Proc. Natl. Acad. Sci. USA. 11:7134-7138.

45. Goldstein, S. M., M. A. Moskowitz, and L. Levine. 1984. Inhibition of stimulated prostaglandin biosynthesis by retinoic acid in smooth muscle cells. Canc. Res. 44:120-125.

46. Chirgwin, J. M., A. E. Pryzbyla, R. J. Macdonald, and W. J. Rutter. 1979. Isolation of biologically active ribonucleic acid from sources enriched in ribonuclease. Biochemistry. 18:5294-5299.

47. Ross, R., C. Nist, B. Kariya, M. J. Rivest, E. Raines, and J. Callis. 1978. Physiological quiescence in plasma-derived serum: influence of platelet-derived growth factor on cell growth in culture. J. Cell. Physiol. 97:497-508.

48. Stiles, C. D., G. T. Capone, C. D. Scher, H. N. Antoniades, J. J. Van Wyk, and W. J. Pledger. 1979. Dual control of cell growth by somatomedins and platelet-derived growth factor. Proc. Natl. Acad. Sci. USA. 76:1279-1283.

49. Montesano, R., L. Orci, and P. Vassalli. 1984. Human endothelial cell cultures: phenotypic modulation by leukocyte interleukins. $J$. Cell. Physiol. 122:424-434.

50. Seifert, R. A., S. M. Schwartz, and D. F. Bowen-Pope. 1984. Developmentally regulated production of platelet-derived growth factor-like molecules. Nature (Lond.). 311:669-671.

51. Sejersen, T., C. Betsholtz, M. Sjolund, C. H. Heldin, B. Westermark, and J. Thyberg. 1986. Rat skeletal myoblasts and arterial smooth muscle cells express the gene for the A chain but not the gene for the B chain (c-sis) of platelet-derived growth factor (PDGF) and produce a PDGF-like protein. Proc. Natl. Acad. Sci. USA. 83:68446848.

52. Walker, L. N., D. F. Bowen-Pope, R. Ross, and M. A. Reidy. 1986. Production of platelet-derived growth factor-like molecules by cultured arterial smooth muscle cells accompanies proliferation after arterial injury. Proc. Natl. Acad. Sci. USA. 83:7311-7315.

53. Majesky, M. W., E. P. Benditt, and S. M. Schwartz. 1988. Expression and developmental control of platelet-derived growth factor A chain and B chain/c-sis genes in rat aorta smooth muscle cells. Proc. Natl. Acad. Sci. USA. In press.

54. Greenberg, M. E., and E. B. Ziff. 1984. Stimulation of 3T3 cells induces transcription of the c-fos proto-oncogene. Nature (Lond.). 311:433-438.

55. Muller, R., R. Bravo, J. Burckhardt, and T. Curran. 1984. Induction of $\mathrm{c}$-fos gene and protein by growth factors precedes activation of c-myc. Nature (Lond.). 312:716-720.

56. Kruijer, W., J. A. Cooper, T. Hunter, and I. M. Verma. 1984. Platelet-derived growth factor induces rapid but transient expression of the c-fos gene and protein. Nature (Lond.). 312:711-716.

57. Kindy, M. S., and G. E. Sonenshein. 1986. Regulation of oncogene expression in cultured aortic smooth muscle cells: post-transcriptional control of c-myc mRNA. J. Biol. Chem. 261:12865-12868.

58. Wyler, D. J., S. Prakash, and P. Libby. 1987. Mesenchymal target cell specificity of egg granuloma-derived fibroblast growth factor in schistosomiasis. J. Infect. Dis. 155:728-736.

59. Cotran, R. S. 1978. Monocytes, proliferation, and glomerulonephritis. J. Lab. Clin. Med. 92:837-840.

60. Rupp, E. A., P. M. Cameron, C. S. Ranawat, J. A. Schmidt, and E. K. Bayne. 1986. Specific bioactivities of monocyte-derived interleukin I alpha and interleukin I beta are similar to each other on cultured murine thymocytes and on cultured human connective tissue cells. J. Clin. Invest. 78:836-839.

61. Jaye, M., R. Howk, W. Burgess, G. A. Ricca, I. M. Chiu, M. W. Ravera, S. J. O'Brien, W. S. Modi, T. Maciag, and W. N. Drohan. 1986. Human endothelial cell growth factor: cloning, nucleotide sequence, and chromosome localization. Science (Wash. DC). 233:541544.

62. Huttner, J. J., E. T. Gwebu, R. V. Panganamala, G. E. Milo, and D. G. Cornwell. 1977. Fatty acids and their prostaglandin derivatives: inhibitors of proliferation in aortic smooth muscle cells. Science (Wash. DC). 197:289-291. 
63. Johnson, G. S., and I. Pastan. 1971. Change in growth and morphology of fibroblasts by prostaglandins. J. Natl. Cancer Inst. 47:1357-1364.

64. Wiley, M. H., K. R. Feingold, C. Grunfeld, V. Quesney-Huneeus, and J. M. Wu. 1983. Evidence for cAMP-independent inhibition of S-phase DNA synthesis by prostaglandins. J. Biol. Chem. 258:491496.

65. Vogel, A., E. Raines, B. Kariya, M. J. Rivest, and R. Ross. 1978. Coordinate control of 3T3 cell proliferation by platelet-derived growth factor and plasma components. Proc. Natl. Acad. Sci. USA. 75:2810-2814.

66. Castellot, J. J., Jr., M. L. Addonizio, R. Rosenberg, and M. J. Karnovsky. 1981. Cultured endothelial cells produce a heparin like inhibitor of smooth muscle cell growth. J. Cell Biol. 90:372-379.
67. Warner, S. J. C., K. R. Auger, and P. Libby. 1987. Interleukin-1 induces interleukin-1. II. Recombinant human interleukin-1 induces interleukin-1 production by adult human vascular endothelial cells. $J$. Immunol. 139:1911-1917.

68. Lovett, D. H., J. L. Ryan, and R. B. Sterzel. 1983. Stimulation of rat mesangial cell proliferation by macrophage interleukin $1 . J$. Immunol. 131:2830-2836.

69. Lovett, D. H., M. Szamel, J. L. Ryan, R. B. Sterzel, D. Gemsa, and K. Resch. 1986. Interleukin 1 and the glomerular mesangium. I. Purification and characterization of a mesangial cell-derived autogrowth factor. J. Immunol. 136:3700-3705.

70. Werber, H. I., S. N. Emancipator, M. L. Tykocinski, and J. R. Sedor. 1987. The interleukin-1 gene is expressed by rat glomerular mesangial cells and is augmented in immune complex glomerulonephritis. J. Immunol. 138:3207-3212. 